NBER WORKING PAPER SERIES

\title{
ARE CONSUMERS AFFECTED BY DURABLE GOODS MAKERS' FINANCIAL DISTRESS? THE CASE OF AUTO MANUFACTURERS
}

\author{
Ali Hortaçsu \\ Gregor Matvos \\ Chad Syverson \\ Sriram Venkataraman \\ Working Paper 16197 \\ http://www.nber.org/papers/w16197 \\ NATIONAL BUREAU OF ECONOMIC RESEARCH \\ 1050 Massachusetts Avenue \\ Cambridge, MA 02138 \\ July 2010
}

We thank Judith Chevalier, Alessandro Gavazza and the participants of the Chicago Booth finance seminar and the NBER Industrial Organization and Corporate Finance meetings for comments and feedback. The views expressed herein are those of the authors and do not necessarily reflect the views of the National Bureau of Economic Research.

NBER working papers are circulated for discussion and comment purposes. They have not been peerreviewed or been subject to the review by the NBER Board of Directors that accompanies official NBER publications.

(C) 2010 by Ali Hortaçsu, Gregor Matvos, Chad Syverson, and Sriram Venkataraman. All rights reserved. Short sections of text, not to exceed two paragraphs, may be quoted without explicit permission provided that full credit, including () notice, is given to the source. 
Are Consumers Affected by Durable Goods Makers' Financial Distress? The Case of Auto

Manufacturers

Ali Hortaçsu, Gregor Matvos, Chad Syverson, and Sriram Venkataraman

NBER Working Paper No. 16197

July 2010

JEL No. D4,G3,L1,L6

\begin{abstract}
The financial decisions of durable goods makers can impose spillovers on their consumers. Namely, durable goods provide a consumption stream that frequently depends on services provided by the manufacturer (e.g., warranties, parts, and maintenance). Manufacturer bankruptcy, or even the possibility thereof, threatens this service provision and can substantially reduce the value of its products to their current owners. We test this hypothesis in one of the largest durable goods markets, automobiles, using data on millions of used cars sold at wholesale auctions around the U.S. during 2006-8. We find that an increase in an auto manufacturer's financial distress results in a contemporaneous drop in the prices of its cars at auction, controlling for a host of other influences on price. The estimated effects are statistically and economically significant. Furthermore, cars with longer expected service lives (those within manufacturer warranty, having lower mileage, or in better condition) see larger price declines than those with shorter remaining lives. These patterns do not seem to be driven solely by reduced demand from auto dealers affiliated with the troubled manufacturers or by contemporaneous declines in new car prices. Our estimates imply a potentially large indirect cost of financial distress on car manufacturers.
\end{abstract}

Ali Hortaçsu
Department of Economics
University of Chicago
1126 East 59th Street
Chicago, IL 60637
and NBER
hortacsu@ uchicago.edu
Gregor Matvos
University of Chicago
Booth School of Business
5807 South Woodlawn Avenue
Chicago, IL 60637
Gregor.Matvos@ chicagobooth.edu
Chad Syverson

University of Chicago

Booth School of Business

5807 S. Woodlawn Ave.

Chicago, IL 60637

and NBER

chad.syverson@chicagobooth.edu

Sriram Venkataraman

Goizueta Business School

1300 Clifton Road NE

Atlanta, Georgia 30322 USA

Sriram_Venkataraman@bus.emory.edu 


\section{Introduction}

Firms' financial decisions have potential spillovers on consumers of durable goods. The consumption stream that durable goods provide frequently depends on product warranties, the availability of spare parts, maintenance and upgrades. For example, a car owner relies on warranties to cover malfunctions early in the car's life, on car parts to be available when the car breaks down, and on the presence of a dealer who can service the car.

As is the case in the car industry, the provision of these and similar services is frequently vertically integrated into the manufacturer. ${ }^{1}$ If a car manufacturer were to go bankrupt, they may not honor the warranties or provide parts and services in the future, reducing the consumption of the durable goods owner. ${ }^{2}$ In fact, the mere expectation of probable bankruptcy may reduce the expected value of durable goods to a forward-looking consumer. Therefore, as firms experience financial distress they impose potentially large spillovers on those who own their goods.

Even though these spillovers are potentially important and large, we have little empirical evidence on the relationship between firms' financial distress and the value of durable goods. It is important to understand this relationship because durable goods represent a significant fraction of household wealth. Automobiles, the subject of our study, account for about 5 percent of consumption in the US and are the nonfinancial asset most commonly held by households. They represented roughly 3 percent of US household wealth in 2007 (Bucks et al. (2009)). Any variation in the value of these assets can expose households to wealth and consumption shocks.

Knowing how firms' financial distress affects owners of durable goods is also critical to understanding firms’ financial decisions. Forward-looking consumers understand that financial distress decreases the probability that future warranties will be honored and parts and services for their car will be available. This reduces demand for the cars of troubled manufacturers. In a 2006 survey, 23 percent of consumers who avoided the "Big 3" (more recently referred to as the

\footnotetext{
${ }^{1}$ Provision of car warranties is generally vertically integrated into the manufacturer, who bundles the warranty with the car. Vertical integration may be natural in this case; it solves the asymmetric information problem present because car manufacturers are best informed about likely future claims on the cars they make. Furthermore, it effectively makes manufacturers the residual claimants on the effort expended toward increasing car durability.

${ }^{2}$ In bankruptcy, warranties are general unsecured claims, in priority after secured claims and other priority claims. An example of this was seen in the marine engine industry with the Chapter 11 bankruptcy of former industry stalwart Outboard Marine Corp. in 2000. According to an article on the case

(http://my.boatus.com/consumer/OMCBankruptcy.asp), the federal trustee assigned to the case said she had "never seen funds set aside in other bankruptcy cases for possible warranty claims in the future” and that while consumers with currently outstanding warranty claims would be able to file proof of claim forms with the court, even they would probably not be paid in full. Further, the article notes that companies that buy assets sold in bankruptcy auctions are not legally obligated to assume warranty liability for products made by the predecessor company.
} 
“Detroit 3”) brands listed those companies’ financial conditions as a reason for avoidance (J.D. Power (2006)). Because of these indirect costs of financial distress, firms may curb the amount of debt used in financing despite the large tax advantages of debt financing. ${ }^{3}$

While the literature since Titman (1984) frequently appeals to indirect costs of financial distress to explain why firms use little debt, there is little direct evidence of such indirect costs in general or in durable goods demand in particular (Hotchkiss et al. (2008)). Measuring the effects of financial distress on the demand for goods is empirically challenging because causality can also operate in the opposite direction: negative demand shocks affect firms' cash flows and therefore can induce financial distress. This generic problem has plagued the literature on the effects of financial distress and indirect costs of bankruptcy, whether these indirect cost are from the consumer, supplier, or employee side. ${ }^{4}$

Our study, besides focusing on an inherently interesting set of products and firms, can avoid many of these identification issues. We study the impact of financial distress on the prices of used cars in car auctions conducted by a major car auction house in the United States from January 1, 2006 to November 14, 2008. We compare shifts in the prices of a manufacturer's cars to a measure of that manufacturer's likelihood of bankruptcy. As we discuss below, we believe our data is rich enough to provide sources of identification of the links between cars' values and their manufacturers' financial distress that are unlikely to be driven by reverse causation, where price drops lead to distress rather than vice versa.

Looking for such effects in used car auctions holds several advantages over new car markets. Wholesale car markets are very liquid; prices can rapidly adjust to changes in the economic environment. Their participants are knowledgeable about the product and the final demand environment. Their decentralized nature makes them less exposed to strategic pricing.

To measure firms’ financial distress levels, we use credit default swaps (CDS) spreads. These are securities whose payoff is conditional on the firm defaulting on its debt, so their price

\footnotetext{
${ }^{3}$ See Titman (1984) for an early discussion of indirect cost of financial distress. Graham (2000) explores the size of debt's tax benefits.

${ }^{4}$ Despite the lack of evidence, the U.S. Treasury Department certainly believed such indirect cost of financial distress have a large impact on car manufacturers, and through warranties in particular. On March 30, 2009, they announced the Warranty Commitment Program, which guaranteed warranties of new General Motors and Chrysler cars were the manufacturers to go bankrupt. They started the program to "help provide much needed certainty to consumers, and a boost to the auto industry, during the restructuring period." We evaluate this assertion in this paper.
} 
reflects the expected probability that a firm enters bankruptcy. Because they are much more liquid than the bonds of the respective companies, they provide the most current measure of companies' financial distress.

We use several sources of variation to address the identification issues plaguing efforts to measure the effect of financial distress on product demand. Our core specification estimates the car price-CDS spread relationship using variation within detailed model-by-region-by-week categories. For instance, we compare the price difference between a 2005 Ford Focus ST sold at an Atlanta auction on Monday and a 2005 Ford Focus ST sold in Ft. Lauderdale later that same week to the change in Ford's CDS spread during the intervening days. Using high-frequency variation makes it less likely that shifts in consumers' views of a particular manufacturer, which presumably operate at a lower frequency, create simultaneous price shifts and financial distress. That said, we observe the negative correlation between a manufacturer's CDS spread and its used car prices at lower frequencies as well. Our basic specification indicates that a 1000-point increase in a manufacturer's CDS spread (a large change, but some firms experience even larger ones in the data) drops the average price of its used cars by $\$ 68$, or about 0.5 percent.

A further testable prediction of our setting is that financial distress should not affect all cars to the same degree. Cars with longer expected remaining service lives should expectedly see a greater price drop when a manufacturer risks bankruptcy, as their flow of lost services would be greater. Further, if car owners worry that their warranties will not be honored upon bankruptcy, then the value of these warranties (capitalized into the price of the car) will fluctuate with manufacturers' financial distress. These effects will imply that value of cars that are still covered under manufacturer warranty or cars with lower mileage should be more affected by financial distress. We find these patterns in the data. The interaction between a car's mileage and its manufacturer's CDS spread is broadly negative, measured in several ways. We directly test for warranty effects and find the CDS effect is significantly larger for cars in warranty.

It is, of course, possible that changes in manufacturer CDS spreads could affect the supply of used cars. In their analysis of a similar used car auction data set to identify how fluctuations in gasoline prices are reflected in the prices and market shares of cars, Busse, Knittel, and Zettelmeyer (2010) point out that both the demand and supply of used cars with different fuel efficiencies may respond differentially to such shocks. Our specifications therefore include 
controls supply-side movements. In particular, we show that the effect is not driven by manufacturers' fire sales of new cars or by the financial distress of the dealers.

We use our estimates to approximate the effect that financial distress has on manufacturers through a decrease in demand for new cars. Using GM as a example, we find the potential size of the effect substantial: even the most conservative estimates yield an 11 percent drop in GM car margins, or alternatively, a 7 percent drop in value of the General Motors North America vehicles division for a 3000 CDS point increase relative to Ford, which is what we observe in the data.

\subsection{Related Literature}

Our paper touches on the previous literature in two distinct ways. First, it directly contributes to the literature on firm capital structure and the indirect cost of financial distress. Since Titman (1984), indirect cost have been used to rationalize the reluctance of firms to used debt financing despite large tax benefits of debt. In their classic paper, Andrade and Kaplan (1998) study thirty one leverage transactions to try to identify the impact of financial distress on firm value. They estimate financial distress cost to be from 10 to 20 percent of firm value. Our paper is closest to Chevalier (1995a, 1995b) and Chevalier and Scharfstein (1996). They also use transaction-level data to study the interaction between financial distress and market outcomes. Their focus is the relationship between supermarkets' financial structures and the pricing decisions in the industry, and in particular the strategic effects of financial distress on entry and markups.

Second, the paper delves into the nature of durable goods markets. Most of the literature on these markets has focused on the interaction between the market for new and used goods, trying to understand the competition a monopolist faces from used goods she sold in the past. ${ }^{5}$ Our paper instead highlights the fact that much of the consumption stream from durable goods depends on future commitments from the manufacturer and other providers of complementary services. To understand the behavior of durable goods suppliers and consumers, we have to understand the complex structure of services that accompany the consumption of durable goods.

The paper is structured as follows. In Section 2 we describe the market for used cars and how it is organized though wholesale auctions. We then describe the data we are using and

\footnotetext{
${ }^{5}$ See Coase (1972), Bulow (1982), and Stokey (1981) for early work on the Coase conjecture.
} 
provide descriptive statistics. In Section 3 we discuss our empirical specification. Section 4 presents and discusses our estimates. In Section 5 we discuss the implications of our estimates for the indirect cost of financial distress on the case of GM. Section 6 concludes.

\section{Institutional Background and Data}

Each year, consumers in the United States buy close to 40 million used vehicles, three times the number of new cars sold. In 2008, for example, there were 36.5 million used vehicle sales ( $\sim 292$ billion in revenues) and 13.2 million new vehicle sales ( $\sim 351$ billion in revenues). While a small fraction of the used vehicles are traded via private party transactions, the lion's share of the used car sales is transacted via the dealer networks. Of the 80,000 auto dealerships in the U.S., nearly 60,000 sell only used cars, while the remaining dealers trade both new and old cars.

These dealers acquire the bulk of their used car inventory via weekly used car auctions conducted at various locations. The auctions are typically wholesale buyers only-they exclude the end consumer. ${ }^{6}$ In general these transactions occur between purchasing dealers and other firms that are car suppliers. Sellers include other dealers, auto manufacturers, rental car agencies and corporate fleet resellers. Dealers often rely on such auctions to adjust their used car portfolios to changing local market conditions. Manufacturers use these auctions sell fleet and program cars. Car rental agencies use these auctions to trade-in their used cars before they get out of factory warranty. Sellers may also be financial institutions who use the wholesale auction to reduce their inventory of program and repossessed cars.

The top five auctioneers cumulatively command approximately an 80 percent market share in the US. While each auctioneer varies in terms of regional distribution and size of operations at each location, physical auction sites managed by major auctioneers are quite large. Each can have between 10 and 100 lanes where automobiles are wheeled through as auctions take place.

Our wholesale auction data comes from a large multinational auctioneer. The firm is the world's largest provider of vehicle remarketing services and is one of the largest wholesale automobile auctioneers in the US, operating eighty-three geographically dispersed auction sites. We use data on over 6 million successfully completed transactions from January 1, 2006 through November 14, 2008. The total value of these sales was about $\$ 89$ billion, with an average

\footnotetext{
${ }^{6}$ Only licensed buyers and sellers who register with the auctioneer can participate in the auction.
} 
transaction price of $\$ 13,000$ per car. The auctioneer runs one or two auction sessions per week at each site, each lasting approximately five hours. Our auctioneer's sites are quite large (see Figure 1a). Table 3 lists select sites and their respective traded volumes. They vary in size from 12 to 98 lanes and in their volume of successful transactions.

On average about 3000 cars sell at each auction location in a given day. Buyers can inspect the car the parking lot prior to the auction session. Each car is provided with a car condition report issued by the auctioneer. This and other vehicle details are prominently displayed in the windshield of each vehicle. Professional auctioneers lead the bidding process, often in the presence of the seller representative (see Figure 1b). When bidding ends, the auctioneer consults the seller's representative or some previously communicated reservation price to determine whether the winning bid is accepted or rejected. Sold or not, the car is then wheeled out and a new vehicle is wheeled in. The entire process takes about thirty seconds per car. Sometimes cars that aren't sold are wheeled back in later in the day. Others are re-auctioned on a future date or even transferred to another site. We observe in the data how many times a car was wheeled in at any auction location before it is sold, as well as sequence in which it was wheeled in (i.e., its run number).

For buyers and sellers who cannot travel to the physical auction site, the firm also uses a proprietary web-based technology that enables both sides of the market to participate in the live physical auctions via real-time audio and video (Figure 1c). Physical auction lanes are equipped with video cameras that allow online users to view the vehicle as it gets wheeled in, observe the physical bidding activity and place their bids via the web. Online users' bids are displayed on the screen located in the physical lane. Large seller consignors like manufacturers and financial institutions can also chose to sell their vehicles via an "upstream” channel that is operated and managed by our market maker. This service gives sellers the ability to remarket their inventory earlier in the remarketing cycle than physical auction lanes. Buyers save on time and travel expenses with desktop access to "Bid or Buy Now" from the largest nationwide selection of wholesale inventory available. Any unsold cars are moved to the physical auction site and sold through the original process.

In our data we know if the winning bid was placed by an online bidder or in-lane bidder or if the car were purchased in the upstream channel. As can be seen in Table 3, approximately ninety percent of the transacted cars were sold to in-lane bidders, eight percent via the upstream 
channel, and the remaining to online bidders. Sometimes consignors restrict their sales to select buyers only, referred to as "closed" sales. Closed marketplaces often serve to benefit a manufacturer's franchise dealer network. Unrestricted or open auctions attempt to allow for maximum buyer participation. 75 percent of the transacted cars in our data were sold in unrestricted auctions (Table 3).

67 percent of the completed transactions are fleet/lease sales, 28 percent factory owned sales, and five percent are dealer-to-dealer sales (Table 3). Each automobile is identified by manufacturer issued unique vehicle information number (VIN). For each VIN we collected information on a large set of vehicle characteristics including car make (Ford, Toyota, Honda, etc.), model (Taurus, Explorer, Altima, etc.), body style (SUV V6, Midsize 4dr V6, 1500 Pickup V12, etc.), and model year. Our data also include the odometer mileage reading and quality condition of each vehicle as certified by the market maker. See Table 2 for details on the quality rating scale.

We obtain the daily time-series of credit default swap spreads with five year maturity (CDS) from Thompson Financial DataStream for all publicly traded automobile manufacturers during the corresponding time period as our auctions data. Figure 2 plots the CDS time series for four manufacturers: General Motors, Ford, Honda and Toyota. The prices are in basis points, which can be interpreted under risk neutrality as default probability. For example, a CDS of 1000 basis points corresponds to 10 percent default probability.

We then match the appropriate CDS series to the auction transaction data using the manufacturer identities in the auction database. ${ }^{7}$ The matching of CDS data and transactions yields a matched database containing 6,188,759 auto sales. Table 4 contains the descriptive statistics of select variables for our final matched data. The data reflect significant variation in price $($ mean $=\$ 13,062$, median $=\$ 12,300$, and s.d. $=\$ 7560)$ and CDS $($ mean $=643.1$ and s.d. $=$ 856.1). The cars vary by mileage, age, and quality condition—from relatively pristine to useful only for salvage. Table 5 describes the price and CDS variation by quality condition (with 0 being salvage ready and 5 being very good), while Table 6 contains descriptive statistics by

\footnotetext{
${ }^{7}$ This yields CDS series for the vast majority of brands in our data, including Acura, Audi, BMW, Buick, Cadillac, Chevrolet, Chrysler, Daewoo, Dodge, Ford, Geo, GMC, Honda, Hummer, Hyundai, Infiniti, Isuzu, Jaguar, Jeep, Land Rover, Lexus, Lincoln, Mazda, Mercedes Benz, Mercury, Mini, Mitsubishi, Nissan, Oldsmobile, Plymouth, Pontiac, Porsche, Saab, Saturn, Scion, Suzuki, Toyota and Volkswagen.
} 
mileage tiers. ${ }^{8}$ As expected, transacted prices fall with quality and age. Note, however, that significant variation exists in the cross-conditions of these two variables; there is significant mileage variation within quality tiers and quality variation within mileage tiers.

\section{Empirical Specification}

Our core specification to measure the effect of financial distress on used cars' values is the following:

$$
p_{i j k l t}=\beta C D S_{i t}+X_{i j k l t} \Gamma+a_{i j k T}+\varepsilon_{i j k l t},
$$

where $i$ indexes manufacturer; $j$ indexes car model, trim, and model year (we will refer to any unique combination of $i$ and $j$ as a “car type”); $k$ indexes auction location (which in most specifications will be one of eight regions in the US), $l$ indexes the specific auction at which the car is sold, $t$ indexes day, and $T$ indexes week. Our dependent variable is the transaction price of the car at auction $p_{i j k l t}$, though we will also estimate specifications below that use a normalized price that divides the transaction price by the average sales price of the car type throughout the entire sample. $C D S_{i t}$ is the manufacturer credit default swap spread in period $t$, and $\beta$ is the coefficient of interest - the estimate of the effect of manufacturer CDS on the price of used cars. The vector $X_{i j k l t}$ contains other controls describing the car and auction characteristics. $a_{i j k T}$ is a car type-region-week fixed effect.

The car-type-region-week fixed effects control for a great number of potentially confounding influences on car prices that might be spuriously correlated with CDS spreads or reflect the impact of reverse causation. This includes fundamental heterogeneity across car types, regionspecific demand and supply shocks for particular vehicles or types of vehicles, and aggregate movements over time. Hence the specification estimates the relationship between car prices and CDS changes only from changes in the auction prices of a given (detailed) type of car within a given region and week.

Intuitively, the regression compares within region-week price differences in cars of manufacturers undergoing financial distress (reflected as an increase in their CDS $_{\text {it }}$ ) with contemporaneous price changes of cars sold in the same region that are made by more financially

\footnotetext{
${ }^{8}$ We use each car's odometer reading to place it into one of twenty non-overlapping mileage bins. The bins divide the sample into equal-sized parts and as such their breakpoints reflect the empirical mileage distribution. We use these bins in some of the specifications below.
} 
stable firms. (Of course, stability per se is not necessary for identification of $\beta$; all that is required is differential changes in spreads across manufacturers.) The regression estimate of $\beta$ simply correlates the differential changes in models' auction prices with the differential changes in the respective manufacturers' CDS spreads, controlling for any fixed or variable effects on prices as captured in $a_{i j k T}$ or $X_{i j k l t}$.

Our choice to limit our identifying CDS price variation to within-week movements may in some ways be overly restrictive, especially if the effects of changes in financial distress take some time to diffuse into wholesale markets. However, restricting ourselves to high-frequency variation in CDS spreads and prices increases the likelihood that we capture the causal impact we seek to measure. It eliminates the possibility that lower-frequency shifts in consumers' views toward a particular manufacturer that both reduce the manufacturer's used car prices and raise its likelihood of bankruptcy are driving our results.

We conduct several additional tests for distress-driven price effects. Each involves specifications that interact the CDS effect with measures that plausibly reflect the extent to which an owner could expect future flows of bundled services. That is, they have the following canonical form:

$$
p_{i j k l t}=\beta C D S_{i t}+\gamma Z_{i j k l t}+\delta\left(Z_{i j k l t} * C D S_{i t}\right)+X_{i j k l t} \Gamma+a_{i j k T}+\varepsilon_{i j k l t},
$$

where $Z_{i j k l t}$ is a car-specific measure of the expected future flows of services. If increased financial distress decreases the expected availability of these services, financial distress should have a larger effect on cars with greater remaining service lives. If service life is positively correlated with $Z_{i j k l t}$, then this would imply $\delta<0$.

We use multiple measures for $Z_{i j k l t}$. One is a set of indicators for 20 equal-sized mileage quantiles. This allows us to flexibly capture the differential impact of financial distress across cars of various mileage levels. Two measures focus on the provision of warranty services in particular (we have gathered data on the coverage period of the cars' original factory warranties). One is an indicator for cars under warranty. This is equal to one if a car meets both its warranty's mileage and age requirements at the time of the auction (e.g., it has under 36,000 miles and is less than 3 years old) and zero otherwise. Specifications estimated using this indicator reflect the average difference in CDS effects on prices for cars that are in and out of warranty. Another warranty variable measures the fraction of the original warranty remains on the car. This is computed as the minimum of two ratios: the difference between the warranty 
mileage limit and the car's current mileage, divided by the mileage limit; and the difference between the warranty age limit and the car's current age, divided by the age limit. Each of the ratios is defined to be zero if the car's current mileage (age) is greater than the warranty limit. This specification imposes an effect of financial distress on prices that linearly changes as a car gets closer to the expiration of its warranty. Still another measure of $Z_{i j k l t}$ that we use is the set of indicators for the auction house's condition rating for cars that were described in Table 2. Low values for the rating indicate cars in poorer conditions, and as such those with shorter expected service lives than other cars of the same make, model, trim level, and model year.

Because our CDS measures do not vary across cars made by the same manufacturer and may also be serially correlated, we cluster all standard errors reported below by manufacturer-month. This allows an arbitrary error correlation structure across cars made by the same manufacturer as well as intertemporally within months.

\section{Results}

A first glance at the data suggests that there may in fact be a link between increases in a manufacturer's financial distress and the value of its used cars. The two panels of Figure 3 compare relative bankruptcy risks and wholesale prices of two manufacturers that experienced considerable financial distress during our sample: Ford and GM. The top panel shows two time series for Ford Motors, both constructed from our data. The solid line shows Ford's CDS spread, which we use to measure its financial distress. The dashed line is the price residual of all Ford used cars sold at auction in our sample. ${ }^{9}$ As is apparent in the figure, during 2008 in particular, as Ford's financial condition worsened, the values of its used cars dropped as well. There is also some indication that as Ford's relative financial condition was improving in late 2006, its vehicles were also rising in relative value. The bottom panel repeats the exercise but replaces Ford with GM, another manufacturer with obvious financial difficulties toward the end of the sample. Again, we see the clear negative correlation in relative prices and financial strength in 2008, but the patterns are less clear prior to that year.

\footnotetext{
${ }^{9}$ We obtain cars' price residuals from a regression that controls for a number of factors that are expectedly invariant to financial conditions. We filter this series through a 12-week moving average in order to reduce statistical noise. In order to remove common movements in price and CDS spreads across manufacturers over the sample, the plotted series are actually the difference between Ford and Honda's respective values. We chose Honda for no special reason other than it was a reasonably financially stable company throughout the sample.
} 
These results are only expository -indeed, our core specifications below don't even use the aggregate, lower-frequency movements shown in the figure to identify the links between distress and used car values—-but they serve to motivate the possibility that such links exist.

\subsection{Baseline Specification}

The patterns seen in Figure 3 suggest that there are negative correlations between manufacturers' CDS spreads and the values of their used cars. However, to try to eliminate as many confounding factors as possible, we will focus below on our more saturated specification that looks at differences within car type-region-week cells.

The results from the first specification of this type are shown in Table 7, column 1. Not surprisingly, given the extent of our included controls, our model does very well explaining the substantial variation in car prices in our sample. The adjusted $\mathrm{R}^{2}$ is 0.986 . The coefficient on manufacturer CDS is -0.068 , with a standard error of 0.021 . The coefficient implies that a 1000 basis point increase in CDS spread leads to a drop in a car's value of $\$ 68$. That is roughly a 0.5 percent drop in value off the average $\$ 13,062$ price of a used car in our sample.

Note that besides the fixed effects, the specification controls for a number of other possibly confounding factors in the data. We include a set of dummies for mileage bins to flexibly capture the effect of mileage on prices. Not surprisingly, average prices decline in mileage. In fact, prices monotonically decrease as one moves from low to high mileage bins. We include dummies for the auction format the car was sold under (this does vary within a day at specific auction locations) and the number of times the car was wheeled through the auction lane, which could be a function of demand or supply factors affecting car price.

One potential worry with our results is that car owners adjust the supply of cars in these auctions when they are affected by the same shocks as the manufacturer. For instance, perhaps rental car companies that have close ties with a particular manufacturer suffer financial shocks that are correlated with those of the manufacturer and are forced to respond by liquidating inventory. This would induce a negative correlation between CDS spreads and prices arising not simply from the manufacturer's financial distress but from supply effects as well. We control for supply effects using two different measures. The first supply control is the number of cars of the same model, trim, and model year being sold on that day in the particular auction location. The 
second measures how many cars of same model, trim, and model year had been sold up to this point in the sample at the same location.

The specification in column 1 of Table 7 uses the car's auction price as a dependent variable. This imposes that the effect of CDS movements has the same absolute size across all cars. Yet it is possible that the absolute effect could be related to the price level of the car rather than independent of it. To account for this possibility, we also run the same specification using as the dependent variable the car's auction price normalized by the average price of its car type (make, model, trim, and model year) throughout the entire sample. In this case, the coefficient on CDS can be interpreted as the size of the effect of financial distress in proportion to the average price level of a car's type.

The results from this specification are shown in Table 7 column 2. Here, the coefficient on manufacturer CDS is $-6.07 \times 10^{-6}$ (s.e. $=1.30 \times 10^{-6}$ ). This implies that for each 1000 basis point increase in CDS spreads, a car's price falls by roughly 0.6 percent. This is essentially the same as the implied percentage change in price from the previous specification using dollar-valued prices. Thus our basic estimated effects are consistent across price measurements.

\subsection{Interactions with Expected Service Lives}

An additional prediction of the financial distress/bundled services link is that the impact of financial distress should vary across cars with different remaining service lives. For example, cars with lower mileage have warranties, and within cars with warranties, have more coverage remaining. They also have longer expected service lives even outside of warranty, so the value of bundled services that their manufacturer provides is also greater. This would suggest that owners of cars with lower mileage should be more exposed to the fluctuations in manufacturers' financial distress.

As discussed previously, we test for these service life effects in several ways. One is to include interact manufacturer CDS spreads with our set of twenty mileage quantile indicators. Table 7, column 3 shows the results of this exercise. We also present the implied relationship between the effect of CDS and car mileage graphically in Figure 4. We can see that, with the exception of the first mileage bin (the excluded category and thus reflected in the main CDS coefficient), the estimated total effects of the interactions are significantly negative for the lowest 14 mileage bins (this corresponds to cars with no more than 50,035 miles). The point estimates 
initially become more negative (i.e., larger in magnitude) as mileage increases, but after reaching an interacted effect of -0.154 in the $8^{\text {th }}$ bin (impling a \$154 dollar price drop for a 1000-point rise in CDS spreads; cars in this bin have 25,766 miles on average), they begin to become more positive. They continue to rise throughout the rest of the mileage bins, and actually become significantly positive by the $17^{\text {th }}$ bin and remain so after.

These results are echoed when we use normalized prices instead of price levels, as seen in Table 7, column 4. There are negative and significant impacts of CDS on cars in the first 15 mileage bins (applying a test for the base effect plus interaction coefficients, the $2^{\text {nd }}$ and $3^{\text {rd }}$ bins are only significant at the 10 percent level). The largest price impact is seen for the $9^{\text {th }}$ bin, as in the price levels specification, after which the interaction becomes more positive. Also in line with the results above, the maximum estimated impact is a one percent price drop per 1000 point CDS increase; the estimated \$154 effect from the levels specification is about 1.2 percent of the average price in the sample. Further, as above, cars in the highest mileage bin see significant price gains when their manufacturer's CDS rise.

We obtain perhaps the most convincing results by focusing on the role of warranties in two specifications. In one, we define an indicator variable denoting if a car is still under original factory warranty. To be defined as such, it must meet both the mileage and age requirements of the warranty. We then test whether the price effects of CDS increases are in fact larger in magnitude (i.e., more negative) for cars under warranty than those out of warranty. In the second warranty check, we compute the fraction of the warranty remaining for a car. (The minimum fraction between the mileage and age limits is used; cars out of warranty receive a value of zero.) We interact this variable with CDS to see if cars with different degrees of remaining warranties see different price effects.

The results using the dichotomous in-warranty indicator are in Table 8, column 1 . The main effect of CDS, and therefore the average impact for cars that are out of warranty, has a coefficient of -0.006 (s.e. $=0.025$ ). Thus the specification implies a negative but insignificant impact on these cars' prices. The interaction, however, has a negative and significant coefficient. The full implied effect of CDS has a coefficient of -0.062 (s.e. $=0.020$ ). This is roughly the size of the main effect estimated above. This is consistent with the threat of the loss of warranty coverage being an important driver of the CDS price effect. 
The second warranty specification, which interacts a measure of the fraction of the factory warranty that remains on the car with the CDS spread, is in Table 8 column 2. The estimated coefficient on the CDS main effect again represents the average impact for cars that are out of warranty and is a statistically insignificant -0.010 . The coefficient on the interaction of CDS and the fraction of warranty remaining, however, is -0.129 , and is significant at the 10 percent level. The fully interacted effect of CDS is -0.139 (s.e. $=0.05$ ), and this is significant at the 1 percent level. This result implies that a car with its full factory warranty remaining (i.e., its fraction is one) would see a price hit of \$139 per 1000 point CDS change, and this then linearly declines until the warranty expires at an insignificant \$10 per 1000 point change. This result therefore has the intuitive property that the effect of CDS on prices falls the shorter is the remaining period over which the warranty applies and during which the car will be operational.

If we linearly extrapolate our warranty estimates for a 10,000 point change in CDS spread, that is, from no chance of bankruptcy to certain bankruptcy, we obtain an approximate valuation of a full warranty in the used car market of $\$ 1390 .^{10}$ It is useful to compare this value to the accounting accruals of warranties in the auto industry, which are between $\$ 400$ to $\$ 2015$ per vehicle. ${ }^{11}$ While these accruals reflect the approximate cost to the manufacturer, and do not take into account the margins charged on the warranties, nor the consumer surplus from the insurance value of warranties, the fact that they are the same order of magnitude suggest our estimates are sensible, even when crudely extrapolated.

We also interact CDS with a measure of the car's physical quality. As mentioned above, the auction house grades cars' conditions on a six-point scale, ranging from 0 (useful for salvage only) to 5 (no or minor defects). This specification tests whether financial distress has different impacts across cars of varying quality by interacting our CDS spread measures with both the car's condition score and its mileage band. The results are presented in Table 8, Column 3. The main CDS effect, which corresponds to the impact on cars in condition category 0 (salvage only) is actually positive and significant. This is consistent with these cars, as a store of available replacement parts, actually becoming more valuable when the manufacturer faces financial distress. However, the size of the coefficient, 0.463, implies what is probably an implausibly large point estimate of a $\$ 463$ price gain when CDS spreads rise by 1000 basis points. Such cars

\footnotetext{
10 This assumes no recovery on warranties in bankruptcy.

${ }^{11}$ http://www.warrantyweek.com/archive/ww20090723.html
} 
represent less than 0.3 percent of the sample, however. Category 1 (poor condition) cars also have a positive total effect of CDS, but this has a more modest (and realistic) coefficient of 0.121. The interactions between categories and CDS continue to fall monotonically as the car's condition improves, as would be expected if better condition cars have longer expected service lives. Those in the best 3 condition categories (3, 4, and 5) all experience significantly negative price effects when CDS rises, on the order of \$56 to \$78 price drops per 1000 point CDS increase.

The results from each of these alternative specifications are consistent with the notion that the negative impact of a manufacturer's financial distress is larger for cars with longer expected remaining service lives, and therefore greater expected future flows of bundled services. There seems to be a special role for warranty coverage in explaining these effects. We have also conducted several robustness checks that we do not report in the paper. The interaction results above are robust to excluding the data after September 15, 2008 (the Lehman Brothers bankruptcy), including car type-auction location-week dummies instead of the car type-regionweek dummies, and estimating the specifications separately for SUV and non-SUV vehicles.

These results also help address the alternative hypothesis that time-varying perceptions of a manufacturer's car quality drive both the manufacturer's CDS spreads and car prices simultaneously. For this alternative story to be true, these innovations in quality perceptions would have to disproportionally affect lower mileage cars, and in particular cars that are under their warranty thresholds. In other words, people's perceptions of the quality of, say, a 2003 Ford Focus with 20,000 miles would have to change very frequently and be highly correlated with Ford's financial condition, while at the same time, there would be virtually no quality updating for a 2003 Ford Focus with 90,000 miles.

\subsection{Robustness Checks}

While it is difficult to imagine an omitted factor that would generate the results above, in particular those regarding expected remaining service life (interactions with mileage, warranty status, and quality), we present further tests to probe the robustness of our results.

To see if, despite all of our controls, our results reflect a spurious correlation between a manufacturer's CDS spread and its used car prices, we conduct a "placebo"-type test. That is, we run our basic specification after having randomly reassigned manufacturers' CDS series 
among one another. In particular, Ford and GM, which experienced CDS growth in 2008 far beyond that of other companies, are assigned the CDS series of Mitsubishi and Toyota. Of course, two more stable manufacturers, Hyundai and Mitsubishi, had, respectively, Ford and GM's CDS values reassigned to them. This placebo specification therefore compares the auction prices of a manufacturer's cars to the CDS prices of another manufacturer. Since reassignment should expectedly destroy any causal link, the coefficient on CDS in this specification should be informative.

The results of this exercise (using the same set of controls as in Table 7 column 1) are shown in Table 9. The coefficient on CDS is now positive and insignificant. Hence it appears that the CDS-price correlations we observed above were tied to within-manufacturer relationships of product values and financial distress.

Our next robustness check investigates whether dealers' (i.e., auto retailers') financial distress, not the preferences of final demanders for bundled services, actually drives the relationship between used car prices and manufacturers' CDS spreads. Namely, if dealers become more concerned about their own business prospects when the manufacturer with whom they are affiliated experiences financial distress, this may reduce their demand for used autos. Moreover, since dealers disproportionately purchase used cars of the same makes that their affiliated manufacturer producers, this could lead to a decline in the prices of that manufacturer's used cars. While one might imagine this is another way a manufacturer's financial decisions can have external effects, it is not the consumer-driven bundled-services channel that is of interest to us here.

To see whether this dealer based-mechanism is driving our results, we take advantage of the fact that our data contains the full name of the winner of every auction. These are nearly always car dealerships, as perusal of the names makes clear. Since dealerships that are affiliated with manufacturers (i.e., those that sell new cars, not just used ones) almost invariantly have the name of the make(s) that they sell new in their name, we can tell when, say, a Ford (or Mercury, Lincoln, or Mazda — all makes that Ford owns partially or outright) dealer buys a used car. If the dealer-based mechanism just described is driving our results, we should expect that Fordaffiliated dealers are less likely to buy Ford cars when Ford's CDS rises. We test whether or not 
this is true for dealers affiliated with the two companies that experienced, by some distance, the greatest amount of financial distress during our sample: Ford and GM. ${ }^{12}$

We do so by estimating a similar specification to our benchmark regression above, with a few exceptions. First, most obviously, the dependent variable is now an indicator equal to one if a Ford dealer (or a GM dealer, in the GM regression) buys the car. Second, we restrict the sample to only cars with a Ford (GM) make. We keep the saturated fixed effect structure from before. Therefore we are testing whether Ford-affiliated (GM-affiliated) dealers are less likely to buy a used car with a Ford (GM) make when Ford's (GM's) CDSs are high, controlling for the average probability across all sales of a particular car type in a region-week. If the dealer-based mechanism is important, we should find a negative and significant coefficient on CDS in this linear probability model.

The results of this estimation are in Table 9, Columns 2 and 3. First off, the coefficient in the GM equation is positive and significant: GM dealers are, if anything, more likely to buy GMmake used cars when GM's CDS rises. Any such effect is pretty small, however. The coefficient implies a 1000-point increase in CDS raises the probability that a GM dealer wins an auction for a GM car by 1.55 percentage points. In the entire sample, 31.6 percent of GM cars are won by a GM-affiliated dealer (most of the rest are won by used-car specialists, though it is not uncommon for new car dealers to purchase across makes when buying used). Thus even a large CDS change doesn't move the probability of purchase far from the baseline. The coefficient in the Ford equation is negative, which is more consistent with a dealer-based mechanism being at work. However, the estimate is marginally statistically significant and is again small in magnitude. A 1000-point increase in Ford's CDS reduces the probability that a Ford-affiliated dealer wins an auction for a Ford-make used car by 1.79 percentage points. On average, however, 38.1 percent of Ford cars are bought by Ford dealers. Thus the likelihood of purchase drops only about 4 percent. It is difficult to know the implied price effect of this reduction without knowing more about the supply of other bidders and their valuations, but this does not seem to be a clear driver of our results above, particularly in light of the GM results.

\footnotetext{
${ }^{12}$ Chrysler was of course having serious troubles during much of our sample. However, they were sold to the private equity firm Cerberus in early 2007, well before the financial crisis began and CDS spreads began to rise. There were no Cerberus CDSs in the market, so we have no way to correlate the manufacturer of Chrysler's financial condition with the prices of its used cars. Thus we dropped all Chrysler cars from our sample from 2007 on.
} 
Our last robustness check addresses the possibility that the relationship between CDS and used car prices is driven by "fire sale" pricing of new cars by car manufacturers. If manufacturers drop prices precipitously as CDS increases, this could spill over into prices of used cars as well. Since our identification comes from within week price variation, this effect is unlikely, since the pricing of new cars would have to be responsive to high frequency variation of CDS. We nevertheless test for this possibility by including the average retail new car price in the region on the day of the sale as a control. The retail price in our new car sales data is computed to reflect the rebates and incentives consumers obtain as well as taking into account the trade in value of the used car. The results are presented in Table 10. The coefficient on new car price is negative, but economically and statistically insignificant. More importantly, we replicate our basic specification and our warranty specifications and find that the results are quantitatively similar after including the new car price. The standard errors are higher and are probably caused by the decreased sample size resulting from matching the used car transaction sample with new car prices.

\section{Discussion}

The results above indicate that auto owners do see a drop in the value of their vehicles when those vehicles' manufacturers are in financial distress. In this section, we do some simple calculations to gauge what our estimates imply about the indirect costs of financial distress that such effects impose back on the car manufacturers themselves. These profit effects act through reduced sale prices for the manufacturers' new cars, which are of course substitutes for the used cars.

To approximate the drop in demand for new cars from our used car estimates above, we conservatively assume that the valuation hit taken by new cars is the same as the estimated drop in the valuation of an (almost-new) used car under full warranty. (This essentially assumes away any "drive off the lot" depreciation that might reduce the size of the effect on used cars.) The estimated drop in valuation for a used car with a full factory warranty remaining is in column 2 of Table 8: every 1000 basis point increase in the manufacturer’s CDS spread leads to a \$139 loss in value. For simplicity, and because it is a reasonable approximation to reality, we assume that manufacturers’ short-run supply curves are inelastic, so this \$139 drop in value is reflected completely in reduced sales prices rather than fewer sales. 
Thus we estimate a car manufacturer can expect a reduction in margin per car of \$139 per 1000 point increase in its CDS spread. To put this magnitude into perspective, we use GM as an example. Between 2006 and 2009, the largest accounting margin that GM earned on its vehicles was 7 percent. ${ }^{13}$ Since estimates of margins in the car industry differ widely, we'll also consider potential margins of 2 and 15 percent. ${ }^{14}$ Suppose the average wholesale (i.e., to-dealer) price of a new vehicle is $\$ 25,000$. At a 2 percent gross margin rate, a manufacturer's per car margin is $\$ 500$; at 7 percent, it is $\$ 1750$; and at 15 percent, it is $\$ 3750$. A 1000 point increase in CDS spread therefore wipes out 28 percent of the per car margin if the margin rate is at our lowest assumed value, 8 percent of the per car margin at the rate observed in GM's data, and just under 4 percent at the highest margin rate we consider. GM's CDS spread had increased to 8000 points by the end of 2008, and exceeded Ford's spread by 3000 points. Even if we assume only the difference between GM and Ford is caused by GM's financial decisions (that is, we let Ford's CDS increase proxy for common factors), the most conservative assumptions imply that GM lost 11.1 percent of its gross margin as an indirect feedback effect of its financial distress. At the margin rate observed in GM's data, the loss is 23.8 percent of gross margins.

Alternatively, we can approximate the present value of cash flows lost to the vehicles division of GM North America because of financial distress, and compare it to our estimate of the enterprise value of the division. GM sold 4.65 million vehicles in North America in 2006. Every 1000 point CDS increase therefore translates in lost cash flows of $\$ 646$ million (= 4.65 million x \$139) per year. At a cost of capital of 10 percent, this implies a loss of approximately $\$ 6.5$ billion in value. To approximate the enterprise value of the vehicles division of GM North America in 2006, we would ideally add the market value of debt and equity of the division, and subtract its cash holdings. However, we can only obtain the equity valuation and book value of debt for GM as a whole, and the book value of debt at this point in time was a poor proxy for its market value. So we instead first assume that GM’s book value of assets, which was $\$ 186.3$ billion at the time, was the market value of the firm. (Given that the firm was headed toward

\footnotetext{
${ }^{13}$ We calculate the accounting margin as (automotive sales/automotive cost of sales) - 1, where the figures are taken from Motors Liquidation Co. 10-K; March 5, 2009.

${ }^{14} 15$ percent is at the lower end of markups estimated by a number of empirical studies of the auto industry using discrete choice demand models. For example, Berry, Levinsohn, Pakes (1995) find, using 1990 data, an average markup of 23.9 percent, and Goldberg (1995) reports an average markup of 38 percent. Using micromoments, Petrin (2002) estimates markups between 15 and 16.7 percent, and the Berry, Levinsohn, Pakes (2004) study with "second-choices" data reports a mean price elasticity of -3.94, implying a markup of 25.4 percent .
} 
bankruptcy, this likely overestimates its value.) We then assume that the vehicle divisions are valued in proportion to their share of cars in GM's overall world production. This will again inflate the value of auto divisions, since it ignores the value of other parts of GM. In 2006 GM sold approximately half of its cars in North America. ${ }^{15}$

This procedure gives an approximate value for GM’s North America auto division at \$93.2 billion. Combining this with the $\$ 6.5$ billion estimated loss in valuation for every 1000 point CDS increase from above implies that a 3000 point increase would have cost GM North America 7 percent $(=6.5 / 93.2)$ of its value. Interestingly, these magnitudes are not far off from those obtained by Andrade and Kaplan (1998) in their work on highly leveraged transactions.

Our assumptions in these calculations are conservative and probably underestimate the impact of financial distress. We should note, however, that as the manufacturer is deeper in financial distress, the expected cost of the warranties that they are offering the customers also declines. The indirect cost of financial distress that arises from warranty is then the difference in the value customers ascribe to these warranties as a part of the bundle with the car and the cost of the warranties to the manufacturer, which might still be significant. While these calculations make many simplifications like ignoring strategic pricing behaviors and production and financing decisions, they nevertheless serve as a useful benchmark in evaluating another implication of our estimates.

\section{Conclusions}

We have shown that durable goods manufacturers’ financial decisions can impose spillovers on their consumers. Firms' financial decisions therefore can impact real outcomes, in this case the consumption of durable goods, and are not neutral in the spirit of the Modigliani-Miller (1958). The proposed channel through which financial distress of manufacturers imposes spillovers is that default can threaten the stream of complementary services (e.g., warranties, spare parts availability, maintenance and upgrades) that the manufacturer provides. As a result, shifts in financial health can impact the value of the manufacturer's products to their current owners.

\footnotetext{
${ }^{15}$ GM sold 4.65 million vehicles in North America and 9.18 million vehicles worldwide in 2008. (Motors Liquidation Co. 10-K, March 05 2009.)
} 
We find evidence that this does in fact hold true for auto manufacturers. Using wholesale auction price data for millions of used cars sold in the U.S. during 2006-8, we show that an increase in an auto manufacturer's financial distress (as measured by an increase in its CDS spread) results in a contemporaneous drop in the prices of its cars at auction, controlling for a host of other influences on price. The estimated effects are statistically and economically significant. A one-point increase in CDS spread results in a 6.8 cent drop in prices. This implies that a 1000 basis point movement in CDS spreads causes a price reduction of $\$ 68$, about 0.5 percent of the average sales price in the sample.

Furthermore, cars with longer expected service lives (under manufacturer warranty, lower mileage or better condition cars) see larger price declines than those with shorter remaining lives. This is consistent with manufacturers' provision of bundled services being an important component of the value of a durable good. There seems to be in particular an important role of warranties in this regard. Additionally, there is some evidence that parts availability might also move prices. High-mileage and low-quality cars actually see price increases when their manufacturer experiences financial distress, and these vehicles might actually be net suppliers of parts rather than net demanders.

We show that these results are robust across a number of specifications with various measurement strategies. They also do not appear to reflect the reduced demand from dealers affiliated with manufacturers experiencing financial distress or a decrease in new car prices driven by manufacturer "fire sales," but rather from the impact on final consumers of the potential loss of a flow of bundled services.

This drop in car demand from financial distress also implies potentially large cost of indirect cost of financial distress for car manufacturers. We hope that our results will motivate future research into the effect of financial distress on new car sales, which has been the topic of much discussion recently given the policy environment, and was explicitly the motivation behind the U.S. Treasury's Warranty Commitment Program. 


\section{References}

Andrade, Gregor and Kaplan, Steven N., 1998, How Costly Is Financial (Not Economic) Distress? Evidence from Highly Leveraged Transactions That Became Distressed, The Journal of Finance, Vol. 53, No. 5, 1443-1493.

Bertrand, Marianne, Duflo, Esther and Mullainathan, Sendhil, 2004, How Much Should We Trust Differences-in-Differences Estimates? Quarterly Journal of Economics, Vol. 119, No. 1, 249-275.

Berry, Steven, Levinsohn, James, Pakes, Ariel, 1995, Automobile Prices in Market Equilibrium, Econometrica, Vol. 63, No. 4, pp. 841-890.

Berry, Steven, Levinsohn, James, Pakes, Ariel, 2004, Estimating Differentiated Product Demand Systems from a Combination of Micro and Macro Data: The Market for New Vehicles, Journal of Political Economy, vol. 112, no. 1,1, pp. 68-105.

Bucks, Brian K., Kennickell, Arthur B., Mach, Traci L. and Moore, Kevin B., 2009, Changes in U.S. Family Finances from 2004 to 2007: Evidence from the Survey of Consumer Finances, Federal Reserve Bulletin, vol. 95, A1-A55.

Bulow, Jeremy I., 1982, Durable-Goods Monopolists, The Journal of Political Economy, Vol. 90, No. 2, 314-332.

Busse, Meghan R., Knittel, Christopher R., Zettelmeyer, Florian, 2009, Pain at the Pump: The Differential Effect of Gasoline Prices on New and Used Automobile Markets, NBER working paper \#15590.

Chevalier, Judith A., 1995a, Do LBO Supermarkets Charge More? An Empirical Analysis of the Effects of LBOs on Supermarket Pricing, The Journal of Finance, Vol. 50, No. 4, 10951112. 
Chevalier, Judith A., 1995b, Capital Structure and Product-Market Competition: Empirical Evidence from the Supermarket Industry, The American Economic Review, Vol. 85, No. 3, 415-435.

Chevalier, Judith A., Scharfstein, David S., 1996, Capital-Market Imperfections and Countercyclical Markups: Theory and Evidence, The American Economic Review, Vol. 86, No. 4, pp. 703-725.

Coase, Ronald H., 1972, Durability and Monopoly, Journal of Law and Economics, Vol. 15, No. $1,143-149$.

Graham, John R., 2000, How big are the tax benefits of debt?, Journal of Finance, Vol 55,19011941.

Goldberg, Pinelopi K., 1995, Product Differentiation and Oligopoly in International Markets: The Case of the U.S. Automobile Industry, Econometrica, Vol. 63, No. 4, pp. 891-951.

Hotchkiss, Edith S., John, Kose, Mooradia, Robert M, and Thorburn, Karin S., 2008, Bankruptcy and The Resolution of Financial Distress, Handbook of Corporate Finance Empirical Corporate Finance, Vol 2.

J.D. Power and Associates, 2006, Domestic Vehicle Avoider Study, 2006 Detroit News, December 11.

Modigliani, Franco, Miller, Merton, 1958, The Cost of Capital, Corporation Finance and the Theory of Investment, American Economic Review, Vol. 48, No. 3, 261-297.

Petrin, Amil, 2002, Quantifying the Benefits of New Products: The Case of the Minivan, Journal of Political Economy, Vol. 110, No. 4, pp. 705-729.

Stokey, Nancy L., 1981, Rational Expectations and Durable Goods Pricing, The Bell Journal of Economics, Vol. 12, No. 1, 112-128. 
Titman, Sheridan, 1984, The effect of capital structure on a firm's liquidation decision, Journal of Financial Economics 13, 137-151. 


\section{Table 1}

\section{Most Common Car Characteristics}

The table presents the most common car characteristics by different variables in our sample. The $\%$ of Obs refers to the $\%$ share of the category among observations for which information was available.

\begin{tabular}{|c|c|c|c|c|c|c|c|}
\hline \multicolumn{4}{|c|}{ Brands } & \multicolumn{4}{|c|}{ Models } \\
\hline Rank & Car Make & \# of Obs. & $\%$ of Obs. & Rank & Car Make & \# of Obs. & $\%$ of Obs. \\
\hline 1 & FORD & $1,387,982$ & 22.43 & 1 & TAURUS & 227,158 & 3.67 \\
\hline 2 & CHEVROLET & 982,143 & 15.87 & 2 & EXPLORER 4WD V6 & 123,892 & 2.00 \\
\hline 3 & NISSAN & 351,425 & 5.68 & 3 & IMPALA & 118,306 & 1.91 \\
\hline 4 & TOYOTA & 313,965 & 5.07 & 4 & ALTIMA & 112,353 & 1.82 \\
\hline 5 & PONTIAC & 285,381 & 4.61 & 5 & GRAND PRIX & 108,419 & 1.75 \\
\hline 6 & JEEP & 255,400 & 4.13 & 6 & FOCUS & 99,004 & 1.60 \\
\hline 7 & DODGE & 216,632 & 3.50 & 7 & F150 PICKUP 4WD V8 & 97,916 & 1.58 \\
\hline 8 & HONDA & 199,190 & 3.22 & 8 & MALIBU V6 & 66,717 & 1.08 \\
\hline 9 & B M W & 170,190 & 2.75 & 9 & F150 PICKUP 2WD V8 & 65,494 & 1.06 \\
\hline 10 & HYUNDAI & 162,162 & 2.62 & 10 & MUSTANG V6 & 64,639 & 1.04 \\
\hline \multicolumn{4}{|c|}{ Model Year } & \multicolumn{4}{|c|}{ Category } \\
\hline Rank & Year & \# of Obs. & $\%$ of Obs. & Rank & Category & \# of Obs. & $\%$ of Obs. \\
\hline 1 & 2006 & $1,278,944$ & 20.67 & 1 & SUV & $1,839,362$ & 29.73 \\
\hline 2 & 2005 & $1,225.995$ & 19.81 & 2 & MIDSIZE CAR & $1,486,014$ & 24.02 \\
\hline 3 & 2004 & 833,631 & 13.47 & 3 & LUXURY CAR & 759,971 & 12.28 \\
\hline 4 & 2007 & 815,163 & 13.17 & 4 & COMPACT CAR & 706,807 & 11.43 \\
\hline 5 & 2003 & 660,975 & 10.68 & 5 & PICKUP & 593,749 & 9.60 \\
\hline 6 & 2002 & 385,805 & 6.23 & 6 & VAN & 464,510 & 7.51 \\
\hline 7 & 2008 & 250,785 & 4.05 & 7 & SPORTS CAR & 184,297 & 2.98 \\
\hline 8 & 2001 & 247,052 & 3.99 & 8 & FULLSIZE CAR & 124,620 & 2.01 \\
\hline 9 & 2000 & 183,006 & 2.96 & 9 & EXCLUDED & 27,080 & 0.44 \\
\hline 10 & 1999 & 124,512 & 2.01 & & & & \\
\hline
\end{tabular}

\section{Car Condition}

\begin{tabular}{rlcc|}
\hline Rank & Condition & \# of Obs. & \% of Obs. \\
\hline 1 & 3 & $3,622,619$ & 58.54 \\
2 & 4 & $1,310,341$ & 21.17 \\
3 & 2 & 918,274 & 14.84 \\
4 & 1 & 174,978 & 2.83 \\
5 & 5 & 141,234 & 2.28 \\
6 & 0 & 21,313 & 0.34 \\
\hline
\end{tabular}


Table 2

\section{Car Condition Levels}

The table provides information on how the different car condition codes are constructed.

\begin{tabular}{|c|c|c|c|c|c|c|}
\hline Grade & 0 & 1 & 2 & 3 & 4 & 5 \\
\hline Paint \& Body & $\begin{array}{l}\text { Good for parts } \\
\text { only } \\
\text { Missing or dis- } \\
\text { connected me- } \\
\text { chanical parts } \\
\\
\text { Operable, but } \\
\text { near the end of } \\
\text { its useful life }\end{array}$ & $\begin{array}{l}\text { Sustained major } \\
\text { collision dam- } \\
\text { age, but may be } \\
\text { drivable } \\
\text { May be cost pro- } \\
\text { hibitive to ex- } \\
\text { tensively recon- } \\
\text { dition this vehi- } \\
\text { cle by industry } \\
\text { standards }\end{array}$ & $\begin{array}{l}\text { Dents, } \\
\text { scratches } \\
\text { and body pan- } \\
\text { els require } \\
\text { replacement } \\
\text { Parts broken } \\
\text { and missing } \\
\text { Multiple prior re- } \\
\text { pairs performed } \\
\text { of substandard } \\
\text { levels } \\
\text { Windshield may } \\
\text { be damaged }\end{array}$ & $\begin{array}{l}\text { Conventional } \\
\text { body and paint } \\
\text { work needed } \\
\text { Requires parts } \\
\text { Sustained cos- } \\
\text { metic/light col- } \\
\text { lision damage } \\
\text { and repaired } \\
\text { to industry } \\
\text { standards } \\
\text { Minor pitting of } \\
\text { glass }\end{array}$ & $\begin{array}{l}\text { Minor conven- } \\
\text { tional body and } \\
\text { paint work } \\
\text { Small dents that } \\
\text { have not broken } \\
\text { the paint } \\
\text { High-quality } \\
\text { conventional } \\
\text { repairs of cos- } \\
\text { metic/light dam- } \\
\text { collision dam- } \\
\text { age }\end{array}$ & $\begin{array}{l}\text { No or minor de- } \\
\text { fects }\end{array}$ \\
\hline Interior & $\begin{array}{l}\text { Mechanical and } \\
\text { body parts may } \\
\text { be inoperable, } \\
\text { disconnected, } \\
\text { damaged or } \\
\text { missing }\end{array}$ & $\begin{array}{l}\text { Operability of } \\
\text { accessories is } \\
\text { doubtful }\end{array}$ & $\begin{array}{l}\text { Signs of excess } \\
\text { wear } \\
\text { Burns, cuts, } \\
\text { tears and non- } \\
\text { removable } \\
\text { stains }\end{array}$ & $\begin{array}{l}\text { Signs of normal } \\
\text { wear and usage } \\
\text { Requires repair } \\
\text { or replacement } \\
\text { of parts }\end{array}$ & $\begin{array}{l}\text { Minimal wear } \\
\text { and minor miss- } \\
\text { ing or broken } \\
\text { parts } \\
\text { No odors }\end{array}$ & $\begin{array}{l}\text { Shows no signs } \\
\text { of wear }\end{array}$ \\
\hline Frame/Unibody & & & $\begin{array}{l}\text { Repaired or un- } \\
\text { repaired frame } \\
\text { structure or } \\
\text { frame damage }\end{array}$ & $\begin{array}{l}\text { No repairs or al- } \\
\text { terations }\end{array}$ & $\begin{array}{l}\text { No repairs or al- } \\
\text { terations }\end{array}$ & $\begin{array}{l}\text { No repairs or al- } \\
\text { terations }\end{array}$ \\
\hline Mechanical & & & $\begin{array}{l}\text { Mechanical } \\
\text { damage that } \\
\text { prohibits opera- } \\
\text { tion properly } \\
\text { Engine and or } \\
\text { transmission in } \\
\text { poor condition } \\
\text { Operability of } \\
\text { accessories is } \\
\text { questionable }\end{array}$ & $\begin{array}{l}\begin{array}{l}\text { Mechanically } \\
\text { sound }\end{array} \\
\text { Requires main- } \\
\text { tenance or mi- } \\
\text { nor repair of ac- } \\
\text { cessories } \\
\text { Fluid levels } \\
\text { low or require } \\
\text { replacement }\end{array}$ & $\begin{array}{l}\text { Sound and op- } \\
\text { erable } \\
\text { Fluids may re- } \\
\text { quire service }\end{array}$ & $\begin{array}{l}\text { Mechanically } \\
\text { sound } \\
\text { Accessories are } \\
\text { operable } \\
\text { Fluid levels full } \\
\text { and clean }\end{array}$ \\
\hline Tires & & & $\begin{array}{l}\text { Worn or mis- } \\
\text { matched }\end{array}$ & $\begin{array}{l}\text { Average or bet- } \\
\text { ter } \\
\text { Match by size } \\
\text { and style }\end{array}$ & $\begin{array}{l}\text { Identical } \\
\text { Good or better } \\
\text { condition }\end{array}$ & $\begin{array}{l}\text { Identical } \\
\text { Near new condi- } \\
\text { tion }\end{array}$ \\
\hline
\end{tabular}


Table 3

\section{Auction Characteristics}

Summary statistics of auction characteristics in our sample. The table contains information on the most common auction locations, whether auctions were closed to non-franchised dealers, the way purchases were transacted, and the source of the used vehicles.

\begin{tabular}{rcc|lcc|ccc}
\hline \multicolumn{2}{c|}{ Auction Open/Closed } & \multicolumn{3}{c|}{ Transaction Type } & \multicolumn{2}{c}{ Vehicle Source } \\
\hline Closed? & \# of Obs. & \% of Obs. & Type & \# of Obs. & $\%$ of Obs. & Source & \# of Obs. & $\%$ of Obs. \\
\hline N & $4,723,193$ & 76.32 & Lane & $5,110,836$ & 82.58 & Fleet/Lease & $4,140,882$ \\
Y & $1,465,566$ & 23.68 & Upstream & 953,435 & 15.41 & Factory & $1,741,028$ & 28.91 \\
& & & Online & 124,488 & 2.01 & Dealer & 306,849 & 4.96 \\
\hline
\end{tabular}

\begin{tabular}{rlrc}
\hline \multicolumn{4}{c}{ Top 10 Auction Locations } \\
\hline Rank & Auction Location & \# of Obs. & \% of Obs. \\
\hline 1 & Pennsylvania & 474,288 & 7.66 \\
2 & Orlando & 269,173 & 4.35 \\
3 & Riverside & 225,562 & 3.64 \\
4 & Nashville & 207,583 & 3.35 \\
5 & Dallas & 203,371 & 3.29 \\
6 & Southern California & 179,224 & 2.90 \\
7 & Chicago & 165,734 & 2.68 \\
8 & New Jersey & 157,914 & 2.55 \\
9 & Georgia & 155,448 & 2.51 \\
10 & Milwaukee & 154,819 & 2.50 \\
\hline
\end{tabular}

Table 4

Summary Statistics of Select Variables

\begin{tabular}{lrrrrr}
\hline Variable & Min & Max & Mean & Median & Sd \\
\hline Run \# & 1 & 3,960 & 185.15 & 121 & 227.64 \\
\# of Wheel-ins & 0 & 80 & 0.30 & 0 & 0.92 \\
Miles & 1 & 999,991 & $44,270.38$ & 31,743 & $36,875.77$ \\
Price & 0 & 341,000 & $13,062.27$ & 12,300 & $7,560.18$ \\
Manuf. CDS & 2.5 & $8,039.70$ & 643.13 & 520 & 856.14 \\
\# of Same Trim Cars That Day & 0 & 443 & 8.98 & 2 & 19.42 \\
\# of Same Trim Cars so Far & 0 & 443 & 3.39 & 0 & 9.44 \\
\hline
\end{tabular}


Table 5

Car Prices and Manufacturer CDS by Car Condition

\begin{tabular}{rrr}
\hline Condition & Avg. Price & Avg. Manuf. CDS \\
\hline 0 & $3,743.25$ & 834.06 \\
1 & $6,753.09$ & 894.28 \\
2 & $8,681.25$ & 635.18 \\
3 & $13,111.68$ & 640.04 \\
4 & $16,340.73$ & 640.99 \\
5 & $19,085.67$ & 453.94 \\
\hline
\end{tabular}

Table 6

Car Prices and Manufacturer CDS by Mileage Bands

\begin{tabular}{rrrr}
\hline Mileage Band & Avg. Mileage & Avg. Price & Avg. Manuf. CDS \\
\hline 1 & $4,818.98$ & $19,823.08$ & 614.32 \\
2 & $10,244.34$ & $17,936.70$ & 649.72 \\
3 & $13,244.71$ & $17,111.88$ & 625.50 \\
4 & $15,880.88$ & $16,573.01$ & 609.78 \\
5 & $18,459.50$ & $16,143.92$ & 603.33 \\
6 & $20,856.87$ & $15,730.07$ & 616.69 \\
7 & $23,214.74$ & $15,149.07$ & 627.93 \\
8 & $25,765.59$ & $14,497.46$ & 638.18 \\
9 & $28,215.15$ & $13,917.72$ & 701.23 \\
10 & $30,416.64$ & $13,901.36$ & 691.40 \\
11 & $33,417.61$ & $14,193.16$ & 644.36 \\
12 & $37,167.25$ & $14,303.58$ & 591.99 \\
13 & $41,836.43$ & $13,882.19$ & 570.29 \\
14 & $47,083.13$ & $13,417.75$ & 553.98 \\
15 & $53,753.09$ & $11,985.07$ & 578.45 \\
16 & $62,320.51$ & $10,172.16$ & 616.94 \\
17 & $73,232.08$ & $8,152.84$ & 678.44 \\
18 & $87,090.39$ & $6,365.74$ & 719.17 \\
19 & $106,344.00$ & $4,744.05$ & 747.39 \\
20 & $152,056.50$ & $3,242.93$ & 783.55 \\
\hline
\end{tabular}




\section{Table 7 \\ Effect of Auto Manufacturers' CDS Spread on Used Car Prices, Baseline Specification}

The dependent variable is the (raw or normalized) transacted price of the used cars in the sample. Manuf. CDS refers to the credit-default swap (CDS) spread (in basis points) of the manufacturers of the used cars. Manuf. CDS $\times$ Band 2-Band 20 denotes the interactions of Manuf. CDS with a set of dummy variables indicating to which of the 20 mileage bands a car belongs. Other controls not reported in the table include dummies for the auction format the car was sold under, the number of times the car was wheeled through the auction lane, and the number of cars of the same model, trim and model year being sold on the same day in the particular auction location. Columns (1) and (3) also include car condition controls. All regressions include car type-region-week fixed effects. Reported standard errors are clustered on car manufacturers $\times$ month, and are reported in parentheses $(* * *$ denotes significance at the $1 \%$ level, ${ }^{* *}$ at the $5 \%$ level, and ${ }^{*}$ at the $10 \%$ level.)

\begin{tabular}{|c|c|c|c|c|}
\hline & (1) & (2) & (3) & (4) \\
\hline Dependent var: & Price & Normalized price & Price & Normalized price \\
\hline Manuf. CDS & $\begin{array}{c}-0.0679^{* * *} \\
(0.0214)\end{array}$ & $\begin{array}{c}-6.07 \mathrm{e}-06^{\star * *} \\
(1.30 \mathrm{e}-06)\end{array}$ & $\begin{array}{r}-0.00514 \\
(0.0340)\end{array}$ & $\begin{array}{c}-4.80 \mathrm{e}-06^{* *} \\
(2.30 \mathrm{e}-06)\end{array}$ \\
\hline Manuf. CDS $\times$ Band 2 & & & $\begin{array}{l}-0.0419^{*} \\
(0.0233)\end{array}$ & $\begin{array}{c}-4.19 e-08 \\
(1.48 e-06)\end{array}$ \\
\hline Manuf. CDS $\times$ Band 3 & & & $\begin{array}{l}-0.0608^{* *} \\
(0.0250)\end{array}$ & $\begin{array}{c}-5.68 \mathrm{e}-07 \\
(1.51 \mathrm{e}-06)\end{array}$ \\
\hline Manuf. CDS $\times$ Band 3 & & & $\begin{array}{c}-0.0854^{\star \star *} \\
(0.0296)\end{array}$ & $\begin{array}{c}-2.01 \mathrm{e}-06 \\
(1.71 \mathrm{e}-06)\end{array}$ \\
\hline Manuf. CDS $\times$ Band 4 & & & $\begin{array}{l}-0.105^{\star * \star} \\
(0.0322)\end{array}$ & $\begin{array}{l}-2.85 e-06^{\star} \\
(1.68 e-06)\end{array}$ \\
\hline Manuf. CDS $\times$ Band 5 & & & $\begin{array}{l}-0.119^{\star * *} \\
(0.0350)\end{array}$ & $\begin{array}{c}-3.44 e-06^{*} \\
(1.83 e-06)\end{array}$ \\
\hline Manuf. CDS $\times$ Band 6 & & & $\begin{array}{l}-0.128^{* * *} \\
(0.0338)\end{array}$ & $\begin{array}{c}-3.79 \mathrm{e}-06^{\star *} \\
(1.60 \mathrm{e}-06)\end{array}$ \\
\hline Manuf. CDS $\times$ Band 7 & & & $\begin{array}{l}-0.143^{* * *} \\
(0.0382)\end{array}$ & $\begin{array}{c}-4.65 e-06^{\star *} \\
(1.90 e-06)\end{array}$ \\
\hline Manuf. CDS $\times$ Band 8 & & & $\begin{array}{l}-0.149^{\star * *} \\
(0.0360)\end{array}$ & $\begin{array}{c}-5.42 e-06^{* * *} \\
(1.77 e-06)\end{array}$ \\
\hline Manuf. CDS $\times$ Band 9 & & & $\begin{array}{l}-0.147^{* \star *} \\
(0.0381)\end{array}$ & $\begin{array}{c}-5.33 e-06^{* * *} \\
(1.56 e-06)\end{array}$ \\
\hline Manuf. CDS $\times$ Band 10 & & & $\begin{array}{l}-0.120^{* * *} \\
(0.0333)\end{array}$ & $\begin{array}{c}-4.10 \mathrm{e}-06^{* * *} \\
(1.38 \mathrm{e}-06)\end{array}$ \\
\hline Manuf. CDS $\times$ Band 11 & & & $\begin{array}{l}-0.132^{* * *} \\
(0.0296)\end{array}$ & $\begin{array}{c}-5.40 \mathrm{e}-06^{\star \star *} \\
(1.47 \mathrm{e}-06)\end{array}$ \\
\hline Manuf. CDS $\times$ Band 12 & & & $\begin{array}{l}-0.108^{* * *} \\
(0.0324)\end{array}$ & $\begin{array}{c}-6.15 \mathrm{e}-06^{\star \star *} \\
(1.96 \mathrm{e}-06)\end{array}$ \\
\hline Manuf. $C D S \times$ Band 13 & & & $\begin{array}{l}-0.0811^{* *} \\
(0.0350)\end{array}$ & $\begin{array}{c}-6.93 e-06^{\star * *} \\
(2.55 e-06)\end{array}$ \\
\hline Manuf. CDS $\times$ Band 14 & & & $\begin{array}{l}-0.00877 \\
(0.0427)\end{array}$ & $\begin{array}{l}-5.60 e-06 \\
(3.90 e-06)\end{array}$ \\
\hline Manuf. CDS $\times$ Band 15 & & & $\begin{array}{c}0.0429 \\
(0.0420)\end{array}$ & $\begin{array}{l}-3.29 e-06 \\
(5.35 e-06)\end{array}$ \\
\hline Manuf. CDS $\times$ Band 16 & & & $\begin{array}{l}0.107^{* *} \\
(0.0450)\end{array}$ & $\begin{array}{c}3.58 \mathrm{e}-06 \\
(6.23 \mathrm{e}-06)\end{array}$ \\
\hline Manuf. CDS $\times$ Band 17 & & & $\begin{array}{l}0.151^{* * *} \\
(0.0466)\end{array}$ & $\begin{array}{l}1.31 \mathrm{e}-05^{\star} \\
(7.28 \mathrm{e}-06)\end{array}$ \\
\hline Manuf. CDS $\times$ Band 18 & & & $\begin{array}{l}0.158^{* * *} \\
(0.0482)\end{array}$ & $\begin{array}{l}1.93 e-05^{\star *} \\
(9.48 e-06)\end{array}$ \\
\hline Manuf. CDS $\times$ Band 19 & & & $\begin{array}{l}0.173^{* * *} \\
(0.0469)\end{array}$ & $\begin{array}{c}3.30 \mathrm{e}-05^{\star * *} \\
(1.23 \mathrm{e}-05)\end{array}$ \\
\hline Constant & $\begin{array}{c}10,768^{\star * *} \\
(142.5)\end{array}$ & $\begin{array}{c}1.198^{\star * *} \\
(0.00317)\end{array}$ & $\begin{array}{c}10,720^{\star * *} \\
(135.3)\end{array}$ & $\begin{array}{c}1.197^{* * *} \\
(0.00354)\end{array}$ \\
\hline Observations & $6,188,759$ & $6,188,725$ & $6,188,759$ & $6,188,725$ \\
\hline R-squared & 0.986 & 0.883 & 0.986 & 0.883 \\
\hline
\end{tabular}




\section{Table 8 \\ Effect of Auto Manufacturers' CDS Spread on Used Car Prices, The Warranty Channel}

The dependent variable is the transacted price of the used cars in the sample. Manuf. CDS refers to the credit-default swap (CDS) spread (in basis points) of the manufacturers of the used cars. "Car in warranty?" is an indicator variable denoting if a car is still under original factory warranty. This is also interacted with the manufacturer CDS. "Fraction of remaining warranty" is calculated as the minimum fraction between the mileage and age limits; cars out of warranty receive a value of zero. We also use the car condition indicators (0-6) defined in Table 2. Other controls not reported in the table include dummies for the auction format the car was sold under, the number of times the car was wheeled through the auction lane, and the number of cars of the same model, trim and model year being sold on the same day in the particular auction location. All regressions also include car type-region-week fixed effects. Reported standard errors are clustered on car manufacturers $\times$ month, and are reported in parentheses $(* * *$ denotes significance at the $1 \%$ level, ${ }^{* *}$ at the $5 \%$ level, and ${ }^{*}$ at the $10 \%$ level.)

\begin{tabular}{|c|c|c|c|}
\hline & (1) & (2) & (3) \\
\hline Dependent var.: & Price & Price & Price \\
\hline Manuf. CDS & $\begin{array}{r}-0.00580 \\
(0.0246)\end{array}$ & $\begin{array}{l}-0.0101 \\
(0.0322)\end{array}$ & $\begin{array}{l}0.463^{* * *} \\
(0.0522)\end{array}$ \\
\hline Car in warranty? & $\begin{array}{l}1,890^{* * *} \\
(32.67)\end{array}$ & & \\
\hline Car in warranty $? \times$ Manuf. CDS & $\begin{array}{l}-0.0565^{* *} \\
(0.0233)\end{array}$ & & \\
\hline Fraction of remaining warranty & & $\begin{array}{c}4,145^{\star * *} \\
(89.42)\end{array}$ & \\
\hline Fraction of remaining warranty $\times$ Manuf. CDS & & $\begin{array}{l}-0.129^{*} \\
(0.0716)\end{array}$ & \\
\hline Condition $1 \times$ Manuf. CDS & & & $\begin{array}{l}-0.342^{\star * \star} \\
(0.0358)\end{array}$ \\
\hline Condition $2 \times$ Manuf. CDS & & & $\begin{array}{l}-0.415^{\star * *} \\
(0.0437)\end{array}$ \\
\hline Condition $3 \times$ Manuf. CDS & & & $\begin{array}{l}-0.518^{* * *} \\
(0.0510)\end{array}$ \\
\hline Condition $4 \times$ Manuf. CDS & & & $\begin{array}{l}-0.527^{\star * *} \\
(0.0542)\end{array}$ \\
\hline Condition $5 \times$ Manuf. CDS & & & $\begin{array}{l}-0.540^{* * *} \\
(0.0690)\end{array}$ \\
\hline Constant & $\begin{array}{l}7,414^{* * *} \\
(124.9)\end{array}$ & $\begin{array}{c}7,283^{* * *} \\
(132.5)\end{array}$ & $\begin{array}{c}8,152^{* * *} \\
(99.80)\end{array}$ \\
\hline Observations & $6,188,759$ & $6,188,759$ & $6,188,759$ \\
\hline R-squared & 0.982 & 0.982 & 0.979 \\
\hline
\end{tabular}




\section{Table 9 \\ Robustness Checks}

The dependent variable in the column (1) is the transacted price of the used cars in the sample. "Placebo" Manuf. CDS refers to not the actual manufacturer CDS, but the CDS of an unrelated manufacturer. In columns (2) and (3), the dependent variable is an indicator for whether the buyer is a GM or a Ford dealer, respectively. These regressions use the CDS of the car's manufacturer. Other controls not reported in the table are as in Table 7, and include dummies for the auction format the car was sold under, the number of times the car was wheeled through the auction lane, and the number of cars of the same model, trim and model year being sold on the same day in the particular auction location. All regressions also include car type-region-week fixed effects. Reported standard errors are clustered on car manufacturers $\times$ month, and are reported in parentheses (*** denotes significance at the $1 \%$ level, ${ }^{* *}$ at the $5 \%$ level, and $*$ at the $10 \%$ level.)

\begin{tabular}{lccc}
\hline & $(1)$ & $(2)$ & $(3)$ \\
\hline Dependent var.: & Price & GM dealer buys & Ford dealer buys \\
\hline "Placebo" Manuf. CDS & 0.047 & & \\
& $(0.0758)$ & & \\
Manuf. CDS & & $1.55 \mathrm{e}-05^{* * *}$ & $-1.69 \mathrm{e}-05^{*}$ \\
& & $(4.89 \mathrm{e}-06)$ & $(1.03 \mathrm{e}-05)$ \\
Constant & $15447^{* * *}$ & $0.299^{* * *}$ & $0.397^{* * *}$ \\
& $(33.10)$ & $(0.00551)$ & $(0.00982)$ \\
Observations & $6,177,673$ & $1,744,349$ & $1,782,919$ \\
R-squared & 0.984 & 0.523 & 0.513 \\
\hline
\end{tabular}


Table 10

Robustness Check: Controlling for New Car Prices

Columns (2) and (3) of this table replicate Columns (1) and (2) of Table ??, but controlling for the new car price on the day of the auction (note that sample size is much smaller as we could not find new car transaction data for many auction days). Column (1) estimates the main effect of manufacturer CDS. As in Table ??, the dependent variable is the transacted price of the used cars in the sample. Manuf. CDS refers to the credit-default swap (CDS) spread (in basis points) of the manufacturers of the used cars. "Car in warranty?" is an indicator variable denoting if a car is still under original factory warranty. This is also interacted with the manufacturer CDS. "Fraction of remaining warranty" is calculated as the minimum fraction between the mileage and age limits; cars out of warranty receive a value of zero. Other controls not reported in the table include dummies for the auction format the car was sold under, the number of times the car was wheeled through the auction lane, and the number of cars of the same model, trim and model year being sold on the same day in the particular auction location. All regressions also include car type-region-week fixed effects. Reported standard errors are clustered on car manufacturers $\times$ month, and are reported in parentheses (*** denotes significance at the $1 \%$ level, $* *$ at the $5 \%$ level, and * at the $10 \%$ level.)

\begin{tabular}{|c|c|c|c|}
\hline & (1) & (2) & (3) \\
\hline Dependent var.: & Price & Price & Price \\
\hline Manuf. CDS & $\begin{array}{l}-0.0775 \\
(0.0599)\end{array}$ & $\begin{array}{c}0.0843 \\
(0.0647)\end{array}$ & $\begin{array}{c}0.0677 \\
(0.0572)\end{array}$ \\
\hline Car in warranty? & & $\begin{array}{l}2038^{\text {*** }} \\
(50.28)\end{array}$ & \\
\hline Car in warranty $? \times$ Manuf. CDS & & $\begin{array}{c}-0.135^{\star * *} \\
(0.0326)\end{array}$ & \\
\hline Fraction of remaining warranty & & & $\begin{array}{l}4721^{\star * *} \\
(134.6)\end{array}$ \\
\hline Fraction of remaining warranty $\times$ Manuf. CDS & & & $\begin{array}{c}-0.333^{* *} \\
(0.152)\end{array}$ \\
\hline New car price & $\begin{array}{l}-0.0019 \\
(0.0032)\end{array}$ & $\begin{array}{l}-0.0023 \\
(0.0033)\end{array}$ & $\begin{array}{c}-0.0018 \\
(0.0033)\end{array}$ \\
\hline Constant & $\begin{array}{c}17,102^{\star \star *} \\
(88.47)\end{array}$ & $\begin{array}{c}13,337^{\star \star *} \\
(83.34)\end{array}$ & $\begin{array}{c}13,333^{* * *} \\
(78.52)\end{array}$ \\
\hline Observations & $1,007,990$ & $1,007,990$ & $1,007,990$ \\
\hline R-squared & 0.980 & 0.975 & 0.977 \\
\hline
\end{tabular}


Figure 1

Illustrative Figures of Used Car Auctions
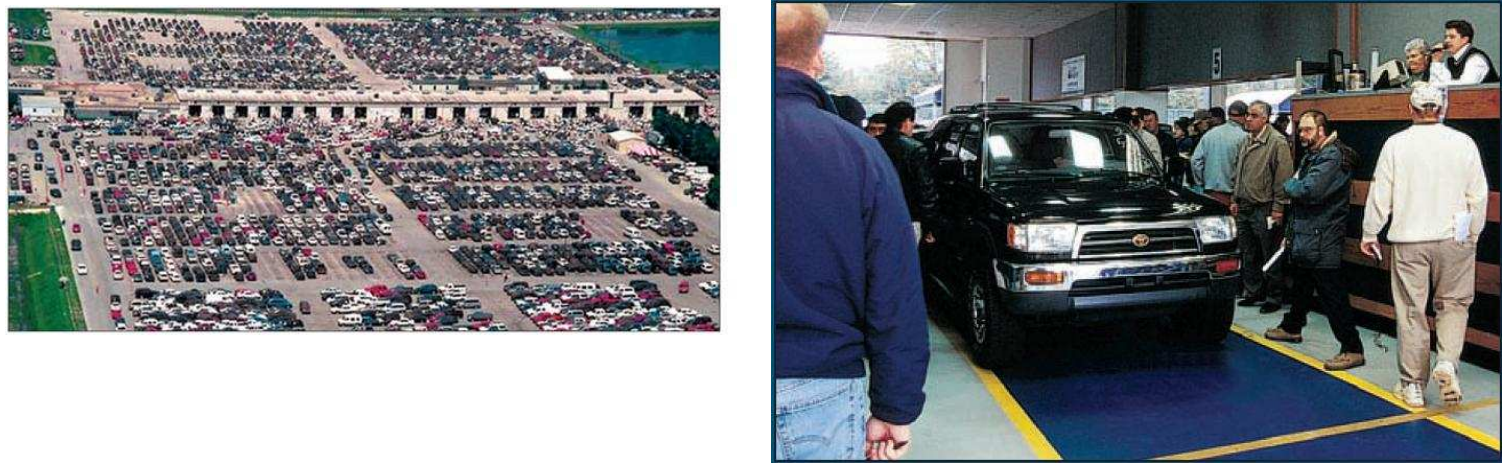

(a) Auction Site

(b) Inside an Auction

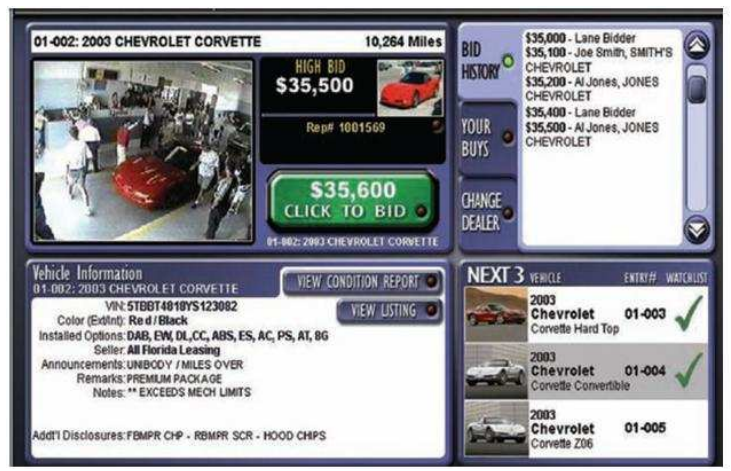

(c) The Auction Online 
Figure 2

Auto Manufacturer CDS Spreads
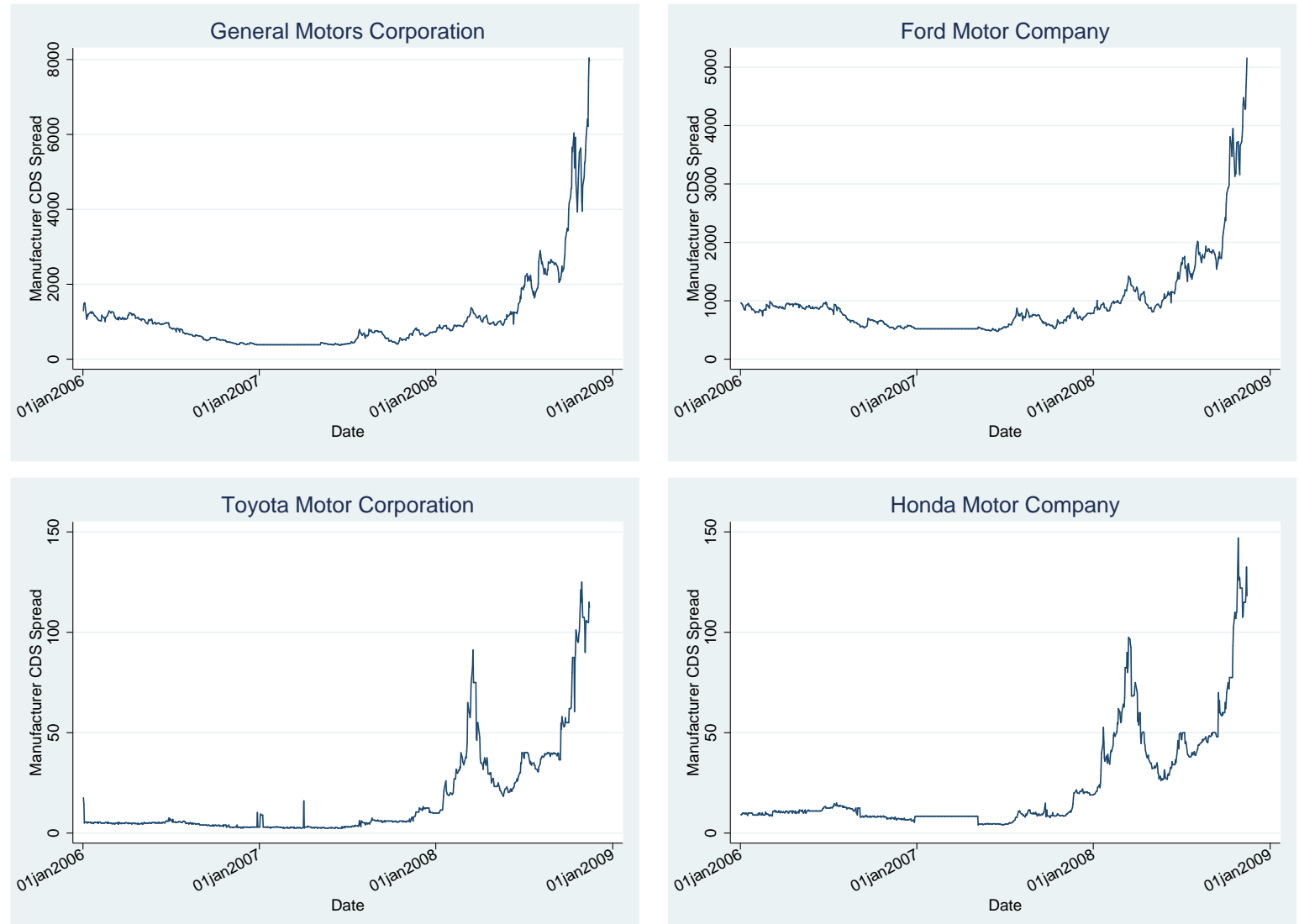


\section{Figure 3}

The panels compare the relative average used car prices and CDS series for Ford (top) and GM (bottom). Each series shows the difference between the appropriate Ford (GM) series and the corresponding series for Honda. The price series are constructed by taking the residual from a regression of cars' auction prices on detailed car type fixed effects, sets of dummies for mileage quantiles, auction location fixed effects, and week-of-year fixed effects. These residuals are averaged by week for every manufacturer, and the difference between Ford's (GM's) and Honda's price series is shown, after smoothing using a 12-week moving average, in the figure. The CDS series are computed by taking the car-weighted average CDS value for each manufacturer and subtracting Honda's series from Ford's (GM's). The log of this difference is shown in the figure to make visualization easier.

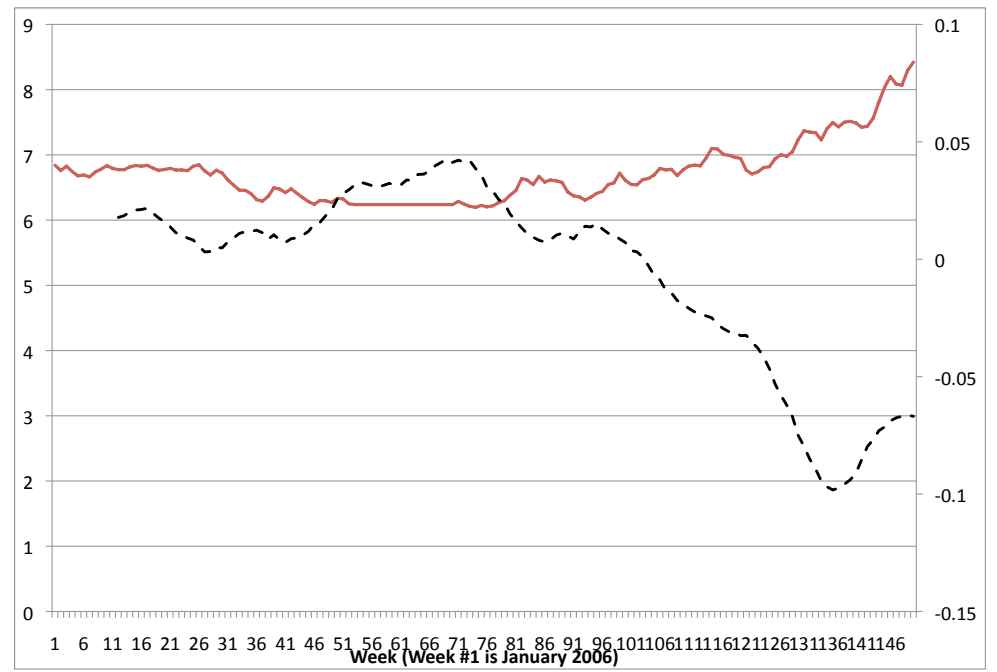

(a) Ford

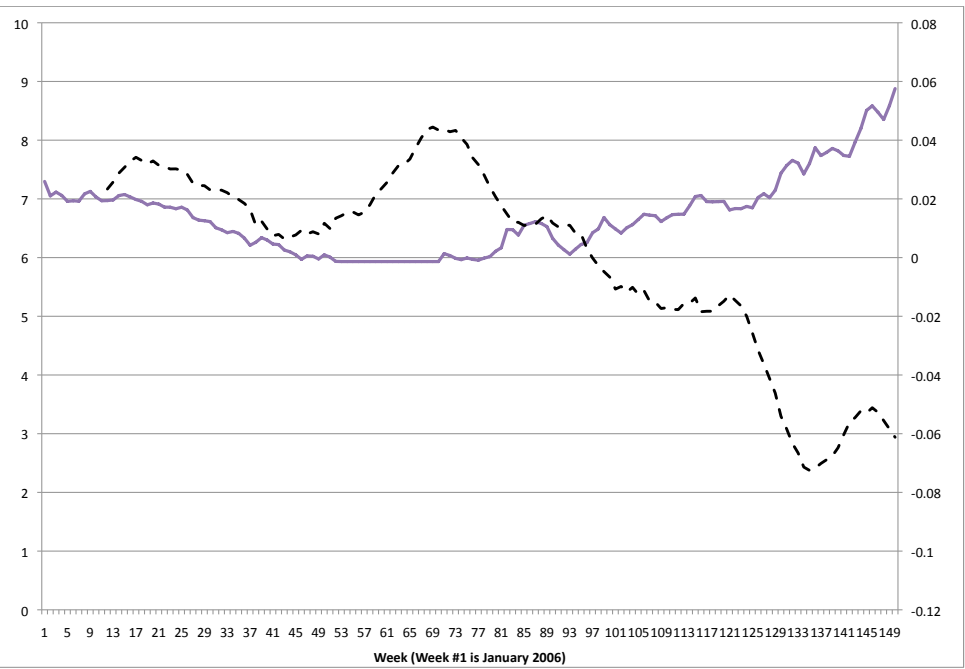

(b) GM 
Figure 4

Plot of Mileage Interaction Coefficients from Column (3) of Table ??

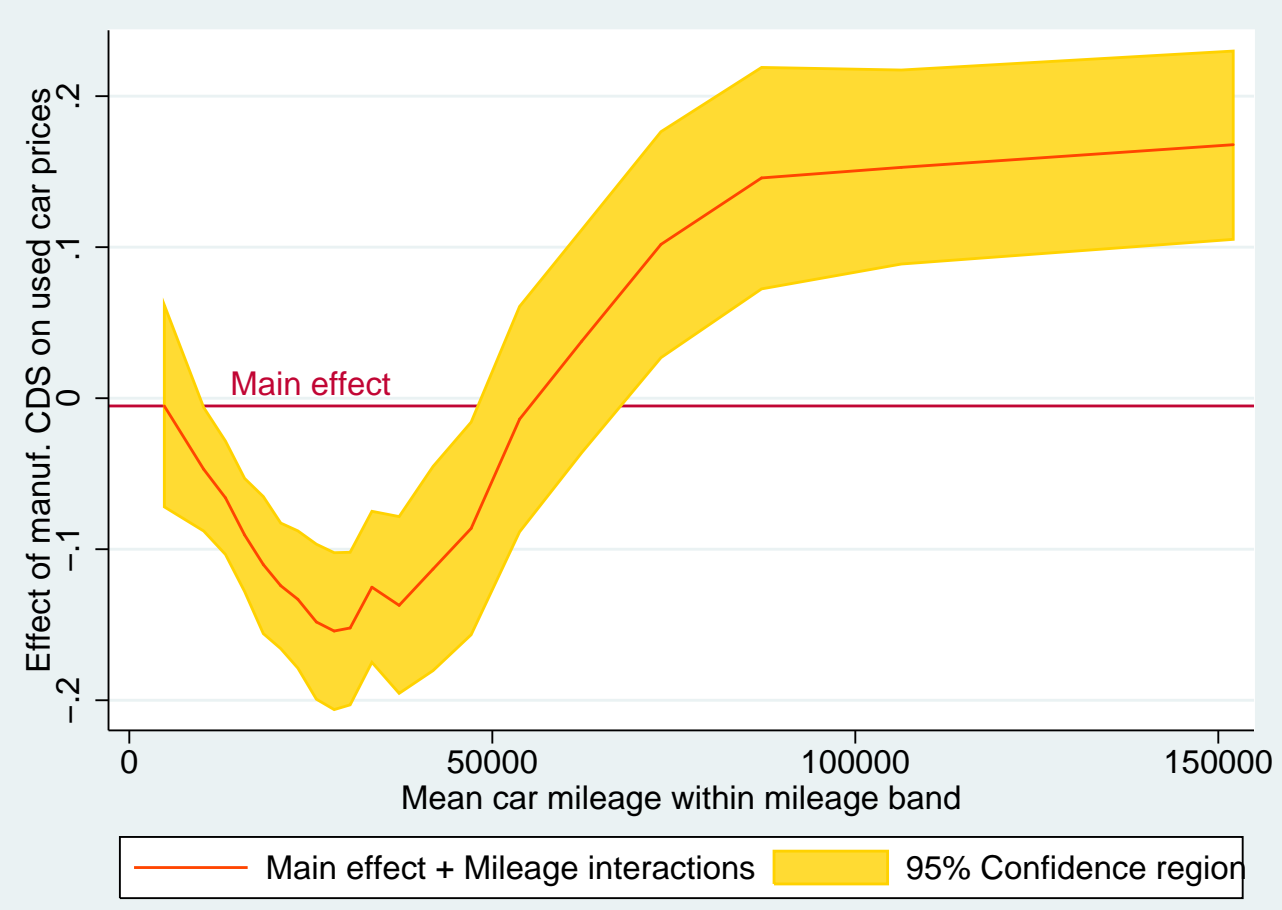

